\title{
Transport of Selected Bacterial Pathogens in Agricultural Soil and Quartz Sand
}

Revised and resubmitted to:

Water Research

November 15, 2008

TIM SCHINNER ${ }^{1}$, ADRIAN LETZNER ${ }^{2}$, STEFAN LIEDTKE², FELIPE D. CASTRO ${ }^{1}$, IRWIN A. EYDELNANT ${ }^{1}$ and NATHALIE TUFENKJI ${ }^{1, *}$

\footnotetext{
${ }^{1}$ Department of Chemical Engineering, McGill University, Montreal, Quebec H3A 2B2, Canada

${ }^{2}$ Biofilm Centre, University of Duisburg-Essen, Duisburg, 47048 Germany
}

\footnotetext{
*Corresponding Author. Phone: (514) 398-2999; Fax: (514)398-6678; E-mail: nathalie.tufenkji@mcgill.ca
} 


\begin{abstract}
The protection of groundwater supplies from microbial contamination necessitates a solid understanding of the key factors controlling the migration and retention of pathogenic organisms through the subsurface environment. The transport behavior of five waterborne pathogens was examined using laboratory-scale columns packed with clean quartz at two solution ionic strengths (10 $\mathrm{mM}$ and $30 \mathrm{mM}$ ). Escherichia coli $\mathrm{O} 157: \mathrm{H} 7$ and Yersinia enterocolitica were selected as representative Gram-negative pathogens, Enterococcus faecalis was selected as a representative Gram-positive organism, and two cyanobacteria (Microcystis aeruginosa and Anabaena flos-aquae) were also studied. The five organisms exhibit differing attachment efficiencies to the quartz sand. The surface (zeta) potential of the microorganisms was characterized over a broad range of $\mathrm{pH}$ values (2-8) at two ionic strengths $(10 \mathrm{mM}$ and $30 \mathrm{mM})$. These measurements are used to evaluate the observed attachment behavior within the context of the DLVO theory of colloidal stability. To better understand the possible link between bacterial transport in model quartz sand systems and natural soil matrices, additional experiments were conducted with two of the selected organisms using columns packed with loamy sand obtained from an agricultural field. This investigation highlights the need for further characterization of waterborne pathogen surface properties and transport behavior over a broader range of environmentally relevant conditions.
\end{abstract}

Keywords: pathogen, transport, filtration, groundwater, Escherichia coli O157:H7, cyanobacteria, agricultural soil, waterborne. 


\section{Introduction}

Walkerton, Ontario and Milwaukee, Wisconsin remain recent reminders of the potential devastation caused by microbial contamination of public drinking water supplies (Smith and Perdek, 2004). According to the World Health Organization, waterborne disease remains the leading cause of death worldwide, with millions of deaths annually attributed to lack of access to clean sources of potable water. Increasing agricultural activity and expanding urbanization contribute to the deterioration of surface water and groundwater quality (Smith and Perdek, 2004).

Worldwide, at least 1.5 billion people depend on groundwater as their sole source of drinking water (World Resources Institute, 2000). Hence, strategies for the prevention and remediation of groundwater contamination are of key importance. The development of groundwater protection policies necessitates knowledge of the fundamental processes controlling the transport and fate of biological and non-biological contaminants in different natural subsurface environments. A good understanding of these mechanisms is also of importance for the correct implementation of riverbank filtration - a process used for the treatment of surface waters aimed at potable use (Tufenkji et al., 2002). A growing research effort has thus been aimed at developing an improved understanding of the migration and retention of microbial pathogens in model or natural granular environments (Castro and Tufenkji, 2007, Dai and Hozalski, 2002, Harter et al., 2000, Hijnen et al., 2005, Tufenkji, 2007).

Many studies examining the interaction of microorganisms with soil, sand, gravel or other model granular materials have been conducted using laboratory-scale columns under wellcontrolled environmental conditions (Bolster et al., 2006, Brown and Jaffe, 2001, Brown et al., 2002, Camesano and Logan, 1998, Castro and Tufenkji, 2007, Dai and Hozalski, 2002, Harter et al., 2000, Harvey and Harms, 2001, Hijnen et al., 2005, Kim et al., 2008, Li and Logan, 1999). 
Laboratory experiments have been conducted to examine the influence of pore water solution chemistry (e.g., salt concentration, $\mathrm{pH}$, ion valence), velocity, matrix moisture content, temperature, and geochemistry (i.e., grain surface properties) on microbial transport and retention in granular porous matrices (Harvey and Harms, 2001). Quartz sand, either clean or coated, and glass beads have all been implemented as model granular materials in such studies. Some researchers have also investigated the transport of microorganisms through columns packed with excavated soils or undisturbed soil cores, yielding additional information regarding the influence of soil chemistry and matrix structure on microbial transport and retention (Banks et al., 2003, Guimaraes et al., 1997, Hekman et al., 1995, Huysman and Verstraete, 1993, Li and Logan, 1999). However, few experimental investigations have aimed to compare the transport behavior of microorganisms in model granular materials (e.g., clean quartz sand or glass beads) with natural sands or soils (Brush et al., 1999, Li and Logan, 1999). Although a large number of studies of microbial transport have been published over the past two decades, our ability to predict the migration potential of bacteria, viruses or protozoa in natural subsurface environments remains limited.

One drawback associated with the current body of literature is the limited number of studies examining the transport and fate of waterborne pathogenic microbes in model or natural granular systems (Brush et al., 1999, Castro and Tufenkji, 2007, Harter et al., 2000, Hijnen et al., 2005). A recent study demonstrated significant transport differences between Shiga-toxin producing Escherichia coli (E. coli) O157:H7 and nontoxigenic surrogates of the same species (Castro and Tufenkji, 2007). Such reports underscore the need for more investigations evaluating the behavior of pathogenic strains of waterborne microbial contaminants. Another limitation of the current literature is the lack of studies examining the transport behavior of Gram-positive organisms. A 
great deal of research has been conducted to evaluate the transport and fate of Gram-negative bacteria, including E. coli, Pseudomonas aeruginosa, and Burkholderia, however, much fewer studies have been conducted with environmentally relevant enteric Gram-positive pathogens such as Enterococcus faecalis (E. faecalis) (Harvey and Harms, 2001).

Recent experimental investigations of microbial transport in granular porous systems have sometimes been accompanied by characterization of the physicochemical properties of the microbes of interest (Bolster et al., 2006, Foppen and Schijven, 2005, Redman et al., 1997, Walker et al., 2004). Measurements of microbe size, shape, surface charge (i.e., zeta potential) and cell surface hydrophobicity have all demonstrated varying levels of relevance in interpretation of microbial transport data (Abu-Lail and Camesano, 2003, Bolster et al., 2006, Castro and Tufenkji, 2007, Dong et al., 2002, Foppen and Schijven, 2005, Redman et al., 1997, Tong et al., 2005, Tufenkji, 2006, Walker et al., 2004). Such measurements are also of interest in understanding the aggregation potential of organisms in aqueous environments (Eboigbodin et al., 2005, Marshall, 1984). Although data relating the surface and physical properties of microbes is of interest in environmental fate studies, such information for waterborne microbial pathogens remains limited (Castro and Tufenkji, 2007, Dai and Hozalski, 2003, Gallardo-Moreno et al., 2003, Hsu and Huang, 2002, Lytle et al., 2002, Lytle et al., 1999, Rivas et al., 2005).

In this study, we investigate the transport potential and physicochemical properties of a broad range of bacterial pathogens. E. coli O157:H7 and Yersinia enterocolitica (Y. enterocolitica) were selected as representative Gram-negative pathogens whereas E. faecalis was selected as a representative Gram-positive fecal indicator. Because of the growing importance of cyanobacteria as surface water contaminants and their relevance as potential contaminants during surface water infiltration (e.g., Groundwater-Under-Direct-Influence (GWUDI) scenarios), the organisms 
Microcystis aeruginosa (M. aeruginosa) and Anabaena flos-aquae (A. flos-aquae) were also examined. Well-controlled laboratory experiments were conducted to evaluate the migration potential of the five organisms in columns packed with clean quartz sand. Two of the organisms (E. coli and E. faecalis) were also studied in columns packed with agricultural soil for comparison with the model granular material. The surface (i.e., zeta) potential of the organisms was characterized over a broad range of solution conditions and the cell size was measured for the condition of the transport experiments. Finally, the experimental results are analyzed within the context of the classic Derjaguin-Landau-Verwey-Overbeek (DLVO) theory of colloidal stability (Derjaguin and Landau, 1941, Verwey and Overbeek, 1948).

\section{Materials and Methods}

2.1. Bacteria Selection and Preparation. The pathogenic or toxigenic organisms used in this study include the two Gram-negative bacteria, E. coli O157:H7 ATCC 700927 and Yersinia enterocolitica (Y. enterocolitica) ATCC 23715, the Gram-positive strain E. faecalis ATCC 29212, and the two cyanobacteria, Microcystis aeruginosa UTCC 299 and Anabaena flos-aquae UTCC 607 (obtained from the University of Toronto Culture Collection of Algae and Cyanobacteria). Pure cultures of E. coli and E. faecalis were maintained at $-80^{\circ} \mathrm{C}$ in Luria-Bertani (LB) Lennox broth (20 g/L, Fisher) with $15 \%$ glycerol. One week prior to inoculation, frozen cultures were streaked onto solid LB agar plates that were then incubated at $37^{\circ} \mathrm{C}$ for $21 \mathrm{~h}$. For each bacterial transport experiment, colonies from the starter plate were used to inoculate $150 \mathrm{~mL}$ of sterile $\mathrm{LB}$ broth (in a $500 \mathrm{~mL}$ baffled flask) which was incubated at $37^{\circ} \mathrm{C}$ and $200 \mathrm{rpm}$ for $18 \mathrm{~h}$ at which point the cells were harvested. This growth protocol does not result in production of Shiga toxins in enteropathogenic $E$. coli. In the case of $Y$. enterocolitica, cells were cultured in the same manner 
as E. coli except the LB medium was replaced with Tryptone Soy Broth (TSB). Both cyanobacteria were incubated in $100 \mathrm{~mL}$ of BG-11 media at $25^{\circ} \mathrm{C}$ and $100 \mathrm{rpm}$ with $12 \mathrm{~h}$ cycles of light and darkness. After incubation, each bacterial suspension was centrifuged (Sorvall RC6) for $15 \mathrm{~min}$ at $5860 \mathrm{~g}$ in an SS-34 rotor (Kendro). The growth medium was decanted and the pellet was resuspended in freshly prepared electrolyte (either $10 \mathrm{mM}$ or $30 \mathrm{mM} \mathrm{KCl}$ solution) adjusted to $\mathrm{pH} 5.9$ using $\mathrm{KOH}$. To remove all traces of the growth medium, the cells were centrifuged and resuspended in fresh electrolyte one additional time. Analytical reagent grade $\mathrm{KCl}, \mathrm{KOH}$ and deionized (Milli-Q) water (DI) were used to prepare the electrolyte solutions. Washed cells were resuspended to a final concentration between $6 \times 10^{7}$ to $5 \times 10^{8}$ cells $/ \mathrm{mL}$ and then maintained at $9^{\circ} \mathrm{C}$ for $21 \mathrm{~h}$ prior to conducting measurements or transport experiments. This cold temperature acclimatization was used to replicate conditions that may be encountered by organisms following their release into natural waters representative of the Canadian climate. All of the organisms used in this study are toxin-producing strains.

2.1. Bacterial Cell Characterization. The nominal size of the bacteria was determined by analyzing images taken in an inverted fluorescent microscope operating in phase contrast mode. An image processing program (ImageJ, NIH) was used to determine the average lengths of the major and minor axes of the cells and the resulting equivalent spherical diameter. At least 100 individual cells were analyzed and the cell size distribution was determined for each organism when suspended in $10 \mathrm{mM} \mathrm{KCl}$ at $\mathrm{pH}$ 5.9.

Microelectrophoresis (ZetaSizer Nano ZS, Malvern) was used to characterize the electrokinetic properties of the organisms when suspended in $10 \mathrm{mM}$ or $30 \mathrm{mM} \mathrm{KCl}$ over a broad range of $\mathrm{pH}$ values (2 to 8). Electrophoretic mobility (EPM) was measured at $15^{\circ} \mathrm{C}$ using cell 
suspensions $\left(6 \times 10^{7}\right.$ to $5 \times 10^{8}$ cells $\left./ \mathrm{mL}\right)$ prepared in the electrolyte of interest. These measurements were repeated using several samples of each bacterial suspension prepared from at least two separate cultures. Bacteria zeta ( $\zeta$ potentials were calculated from the measured EPMs using the Smoluchowski equation (Hunter, 2001).

\subsection{Bacterial Transport Studies. Column experiments were conducted to evaluate the transport} behavior of the five microorganisms separately in $10 \mathrm{mM}$ and $30 \mathrm{mM} \mathrm{KCl}$ solution at $\mathrm{pH} 5.9$ in quartz sand columns. The column apparatus was placed inside a cold chamber maintained at $15^{\circ} \mathrm{C}$. Preparing cell suspensions at a slightly colder temperature $\left(9^{\circ} \mathrm{C}\right.$; see above) facilitated conducting the experiment at $15^{\circ} \mathrm{C}$ (due to slight heat gain by the suspension during preparation of the experiment). Experiments were conducted by pumping (model 200 syringe pump, KD Scientific) a bacterial suspension through a glass column (with an inner diameter of $1 \mathrm{~cm}$ ) packed with electrolyte-saturated high purity quartz sand (Granusil \#2040, Ottawa Plant, Unimin). The quartz sand has a mean grain diameter $\left(d_{50}\right)$ of $0.763 \mathrm{~mm}$ and a coefficient of uniformity, $d_{60} / d_{10}$, of 1.2. Quartz sand was wet-packed to a height of $89 \mathrm{~mm}$ with vibration to minimize layering and air entrapment. Selected experiments were conducted with the representative Gram-negative pathogen E. coli $\mathrm{O} 157: \mathrm{H} 7$ and the Gram-positive pathogen E. faecalis in columns packed with natural agricultural soil (Macdonald Farm, Ste-Anne-de-Bellevue, Quebec). Standard soil analysis revealed the collected soil to be a loamy sand ( $85 \%$ sand, $9.7 \%$ silt, and $5.3 \%$ clay). The agricultural soil was dry-packed into a glass column (with an inner diameter of $1.6 \mathrm{~cm}$ ), purged with $\mathrm{CO}_{2}$, then water-saturated to obtain a final packed column height of $65 \mathrm{~mm}$. The porosity of the quartz sand column was determined to be 0.35 and that of the natural soil was evaluated as 0.42 . 
Prior to each experiment, the packed column was equilibrated by injecting at least 25 pore volumes (PV) of background electrolyte solution $(10 \mathrm{mM}$ or $30 \mathrm{mM} \mathrm{KCl})$ through the column at a flow rate of $0.8 \mathrm{~mL} / \mathrm{min}$. In experiments conducted with natural soil, the packed column was flushed with $7 \mathrm{PV}$ of DI water prior to equilibrating with electrolyte. After equilibrating the packed column, a bacterial suspension in the same electrolyte solution was flowed through the column for at least $5 \mathrm{PV}$ followed by a bacteria-free electrolyte solution to elute all cells that were not retained on the sand or soil grains. In experiments conducted with clean quartz sand, bacterial cell concentration at the column outlet was monitored online with a UV/visible spectrophotometer (Hewlett-Packard Model 8453) using a $1 \mathrm{~cm}$ flow-through cell (at $600 \mathrm{~nm}$ ). At the cell concentrations used in this study, the bacterial cell concentration was linearly correlated with the spectrophotometer measurements at a wavelength of $600 \mathrm{~nm}$. In experiments conducted using natural soil, samples of the column effluent were collected in sterile eppendorf tubes and examined with the spectrophotometer using a quartz cell. In selected experiments with natural soil, two additional bacteria enumeration methods were used for comparison. Specifically, effluent samples were analyzed by (i) standard spread plating technique using R2A agar plates, and (ii) direct epifluorescence microscopy (BacLight, Invitrogen). Each column experiment was conducted at least twice and good reproducibility was observed in the measured bacteria breakthrough curves.

2.4. Interpretation of Bacterial Column Experiments. Classical colloid filtration theory (CFT) was used to quantitatively compare the microbial attachment behavior to quartz sand and agricultural soil. The attachment efficiency $(\alpha)$ in CFT is a useful parameter to compare microbial transport and retention observed under different conditions and was calculated from each breakthrough curve as follows (Yao et al., 1971): 


$$
\alpha=-\frac{2}{3} \frac{d_{\mathrm{c}}}{(1-\varepsilon) L \eta_{0}} \ln \left(C / C_{0}\right)
$$

where $d_{\mathrm{c}}$ is the diameter of the sand/soil grains, $\varepsilon$ is the bed porosity, $L$ is the bed length, and $\eta_{0}$ is the theoretical single-collector contact efficiency evaluated using a recently developed correlation equation (Tufenkji and Elimelech, 2004). The value of $C / C_{0}$ in equation 1 was obtained from the experimental breakthrough curves during the initial (clean-bed) phase of bacterial elution where CFT is valid; specifically, the average value of $C / C_{0}$ measured between pore volumes 1.9 and 2.1 was used. It should be noted that CFT is valid for clean-bed filtration where it is assumed that deposited particles or cells do not influence subsequent deposition of colloids.

\section{Results and Discussion}

3.1. Electrokinetic Properties of Bacteria. The $\zeta$-potential of different Gram-negative and Gram-positive bacteria was determined over a broad range of $\mathrm{pH}$ values (2 to 8 ) and at two different solution ionic strengths (IS). Figure 1a compares the $\zeta$-potentials of the five selected microbes when suspended in $10 \mathrm{mM} \mathrm{KCl}$. All of the microbes examined are negatively charged over most of the $\mathrm{pH}$ range and exhibit an increase in the magnitude of charge with increasing $\mathrm{pH}$. This behavior can be explained by the increased deprotonation of cell surface functional groups with the addition of base. In general, the organisms have a $\mathrm{pH}_{\mathrm{zpc}}$ around $\mathrm{pH} 2.5$ (with the exception of the Gram-positive E. faecalis which has a lower $\mathrm{pH}_{\mathrm{zpc}}$ ). The Gram-negative pathogen E. coli O157:H7 exhibits the lowest absolute $\zeta$-potential which does not become more negative than -2 $\mathrm{mV}$ over the range of conditions examined. In contrast, $Y$. enterocolitica is the most negatively charged organism at environmentally relevant $\mathrm{pH}$ values (i.e., between $\mathrm{pH} 5$ and 8). 

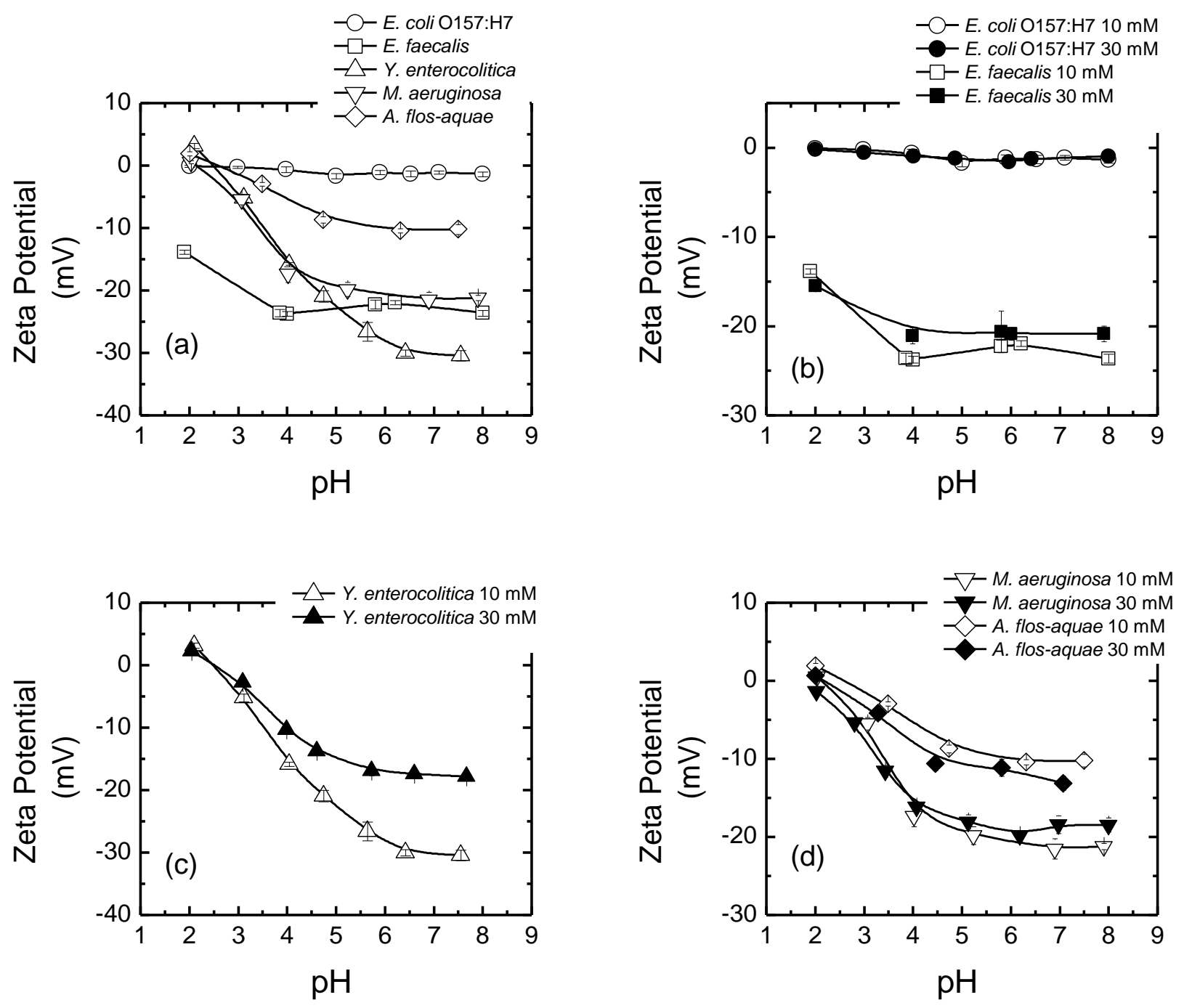

FIGURE 1. Bacteria $\zeta$-potential of (a) the five selected organisms at $10 \mathrm{mM} \mathrm{IS;} \mathrm{(b)} \mathrm{E.} \mathrm{coli} \mathrm{O157:H7}$ and E. faecalis in $10 \mathrm{mM}$ and $30 \mathrm{mM} \mathrm{KCl}$; (c) Y. enterocolitica in $10 \mathrm{mM}$ and $30 \mathrm{mM} \mathrm{KCl;} \mathrm{(d)}$ Microcystis aeruginosa and Anabaena flos-aquae in $10 \mathrm{mM}$ and $30 \mathrm{mM} \mathrm{KCl}$. 
Figures $1 \mathrm{~b}$-d allow for comparison of the bacteria $\zeta$-potentials measured in $10 \mathrm{mM}$ and 30 $\mathrm{mM} \mathrm{KCl}$. In general, the bacteria $\zeta$-potential is less negative in $30 \mathrm{mM} \mathrm{KCl}$ as a result of increased compression of the diffuse layer of ions surrounding the cell at this higher ion concentration. Such behavior has been demonstrated for a wide range of non-biological and biological colloids (Brant et al., 2005, De Kerchove and Elimelech, 2005, Kuznar and Elimelech, 2004, van der Wal et al., 1997). The $\zeta$-potential of E. coli $\mathrm{O} 157: \mathrm{H} 7$ is comparable to previously published data for this organism (Bolster et al., 2006, Lytle et al., 1999). The $\zeta$-potential of E. faecalis, $Y$. enterocolitica and the two cyanobacteria has been reported for very limited solution conditions (GallardoMoreno et al., 2003, Jameson, 1999, van Merode et al., 2006). Van Merode et al (2006) report a $\zeta$-potential between -24 and $-40 \mathrm{mV}$ for $E$. faecalis measured in $10 \mathrm{mM}$ potassium phosphate at $\mathrm{pH}$ 7. In Figure 1a, it can be noted that the $\zeta$-potential of E. faecalis measured in $10 \mathrm{mM} \mathrm{KCl}$ is $-24 \mathrm{mV}$ between $\mathrm{pH} 4$ and 8 . The $\zeta$-potential of $Y$. enterocolitica is presented in Figure 1c. Over most of the environmentally relevant $\mathrm{pH}$ range (i.e., $\mathrm{pH} 5$ to 8), there is a considerable difference in the $\zeta$-potential determined at the two IS. The $\zeta$-potential of $M$. aeruginosa was previously reported to be between -25 and $-30 \mathrm{mV}$ at $\mathrm{pH} 9.5$ (Jameson, 1999). Figure 1d indicates that the $\zeta$-potential for this organism is near zero at $\mathrm{pH} 2$ and approaches $-25 \mathrm{mV}$ at $\mathrm{pH} 8$ (in $10 \mathrm{mM} \mathrm{KCl}$ ). In the case of A. flos-aquae (Fig 1d), the $\zeta$-potential seems to be more negative at the higher IS (30 $\mathrm{mM}$ ). However, it should be noted that this organism exists in the form of long chains (as will be discussed in section 3.2.) and exhibits a highly nonuniform size distribution. Hence, the ZetaSizer measurements reported for this organism are to be considered with caution. Because $\zeta$-potential is an important parameter governing colloid stability, the measurements presented in Figure 1 may provide insights into the transport and aggregation potential of each organism in aqueous 
environments. The possible links between cell $\zeta$-potential and bacterial transport behavior will be discussed in more detail further in the paper.

3.2. Bacteria Sizing. The importance of cell size and shape has been reported in several studies of colloidal transport and retention in granular porous media (Salerno et al., 2006, Weiss et al., 1995, Xu et al., 2008). Cell sizing was carried out by analysis of microscope images to better understand the inherent variability in size within a population of bacteria obtained from a pure culture as well as the differences in cell size between the different organisms selected. Bacterial cell size distributions for selected organisms (E. coli O157:H7, E. faecalis, Y. enterocolitica) are presented in Figure 2a, where cell size is reported as the equivalent spherical diameter (ESD) based on the average lengths of the major and minor axes of individual cells. 


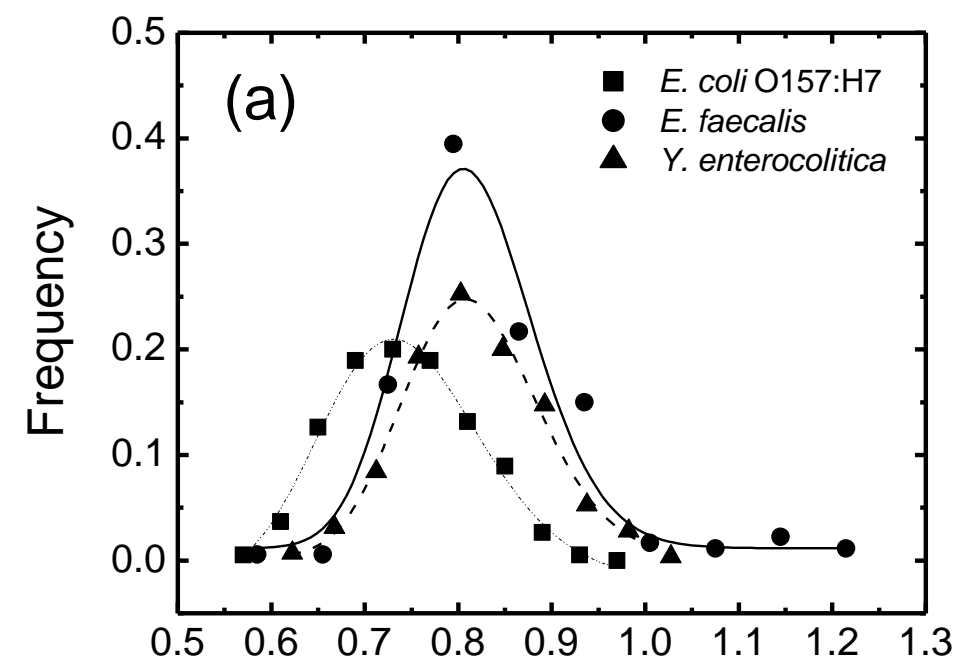

Equivalent Spherical Diameter

$(\mu \mathrm{m})$

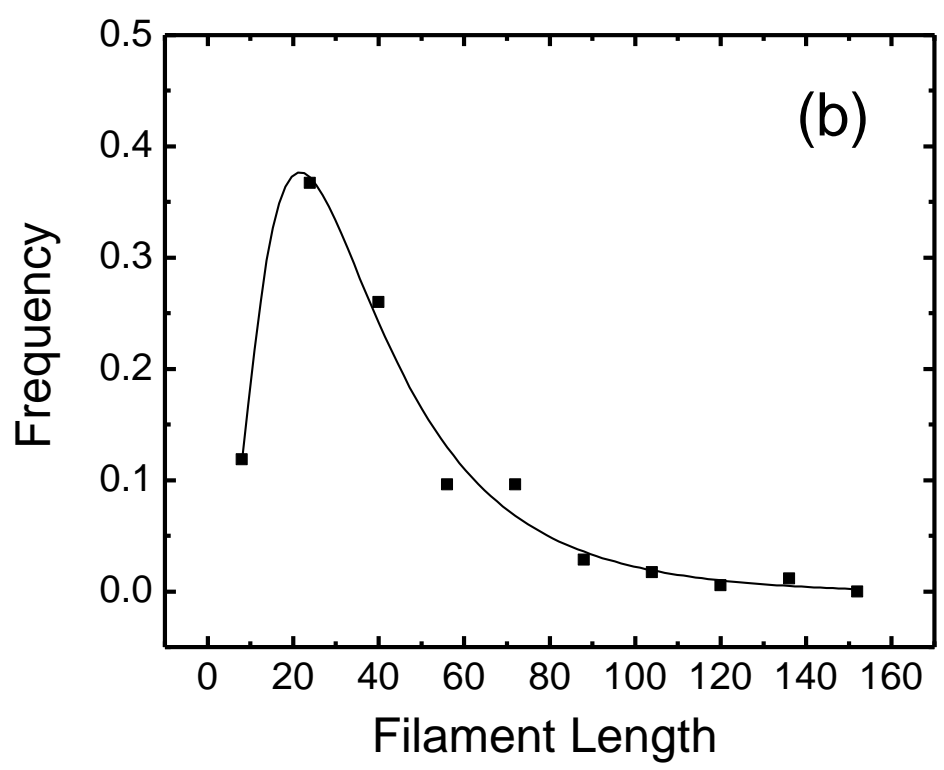

$(\mu \mathrm{m})$

FIGURE 2. (a) Distributions of bacteria cell size (equivalent spherical diameter) based on microscope image analysis for E. coli O157:H7, E. faecalis, and Y. enterocolitica, and (b) distribution of filament length determined by microscope image analysis for A. flos-aquae. Lines in the plots are curve fits that have been included as eye guides. 
The median cell size $\left(E S D_{50}\right)$ of $E$. coli $0157: \mathrm{H} 7$ is $0.74 \mu \mathrm{m}$, whereas that of $Y$. enterocolitica is $0.82 \mu \mathrm{m}$ (Fig. 2a). E. faecalis is cocci shaped and commonly observed as doublets with a median cell size of $0.84 \mu \mathrm{m}$. In comparison to the three pathogenic bacteria, the two cyanobacteria were much larger in size. Microcystis aeruginosa was commonly observed as dividing doublets with a $E S D_{50}$ of $2.6 \mu \mathrm{m}$, whereas Anabaena flos-aquae are found as extended strands of cells as long as $160 \mu \mathrm{m}$ (Fig. 2b). The sizing analysis demonstrates the significant variability in cell size within the monoclonal populations. As discussed previously, the nominal size of the cells may play an important role in their transport and fate in aqueous environments; however, the distribution in cell size can also be a key factor in the prediction of transport behavior. For instance, in the case of bacteria exhibiting a wider size distribution, transport predictions based on the median cell size may significantly over-predict or under-predict their true migration or straining potential.

3.3. Transport and Retention of Pathogens in Quartz Sand. In this section, we present the results of transport experiments conducted with the five selected organisms using laboratory columns packed with clean quartz sand. Experiments were conducted at an adjusted pH of 5.9 in both $10 \mathrm{mM}$ and $30 \mathrm{mM} \mathrm{KCl}$ solutions (with the exception of A. flos-aquae which was only examined at $10 \mathrm{mM}$ ). Representative breakthrough curves for experiments conducted with $E$. faecalis, A. flos-aquae, and M. aeruginosa at $10 \mathrm{mM}$ IS are shown in Figure 3 where the normalized effluent cell concentration is plotted as a function of time. The absorbance measurements show that the cell concentration in the column effluent rapidly reaches a steadystate value. In the case of A. flos-aquae, the breakthrough exhibits a slight increase in 
concentration at approximately $750 \mathrm{sec}$, suggesting that blocking is occurring in the column due to the high extent of cell retention (Bolster et al., 2001, Rijnaarts et al., 1996a).

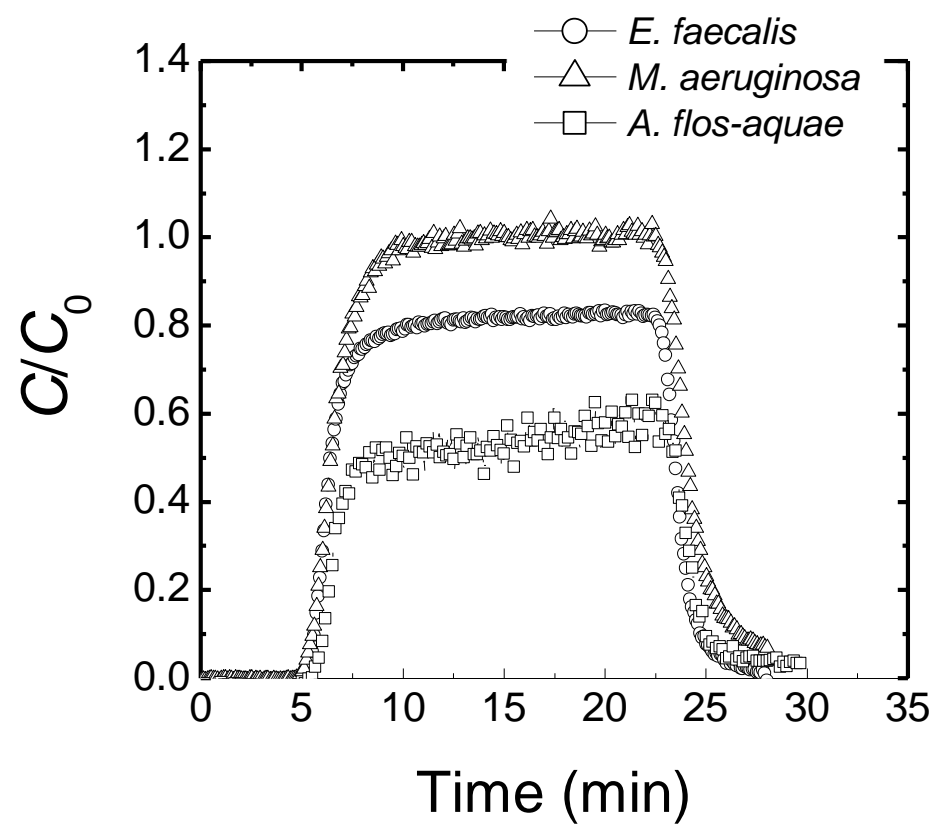

FIGURE 3. Representative breakthrough curves for transport of E. faecalis, M. aeruginosa, and A. flosaquae in columns packed with clean quartz sand (10 mM IS, pH 5.9). The column diameter was $1.0 \mathrm{~cm}$ and the fluid superficial velocity was $1.7 \times 10-4 \mathrm{~m} / \mathrm{sec}$ (flow rate of $0.8 \mathrm{~mL} / \mathrm{min}$ ).

To quantitatively compare the filtration behavior of the five selected bacteria, the attachment efficiency $(\alpha)$ was calculated using eq 1 and the clean-bed normalized cell concentration $\left(C / C_{\mathrm{o}}\right)$ measured for each organism. Figure 4 shows the $\alpha$ values for the 5 organisms when transported through a column packed with clean quartz sand. In general, the bacterial attachment efficiency is greater at higher solution IS, or has already reached the maximum transport rate at the lower IS examined. Y. enterocolitica and M. aeruginosa both exhibit higher $\alpha$ values at $30 \mathrm{mM}$. An increase in bacterial attachment with increasing salt concentration is in qualitative agreement with the DLVO theory of colloidal stability. As the concentration of $\mathrm{KCl}$ in the solution increases, the diffuse double layers surrounding the bacteria and the sand grains are 
compressed, causing a reduction in the repulsive electrostatic double-layer forces and a corresponding increase in the bacterial deposition rate. The observed increase in cell retention with solution IS has been previously demonstrated in column studies using various bacterial species and strains (Castro and Tufenkji, 2007, Rijnaarts et al., 1996b, Walker et al., 2004). In the case of E. coli $\mathrm{O} 157: \mathrm{H} 7$ and E. faecalis, the $\alpha$ value is similar at the two IS examined and approximately equal to 1 . This observation can be attributed to the fact that the maximum deposition rate onto quartz sand for these organisms is reached at a relatively low solution IS, and hence, any subsequent increase in salt concentration does not yield a higher deposition rate.

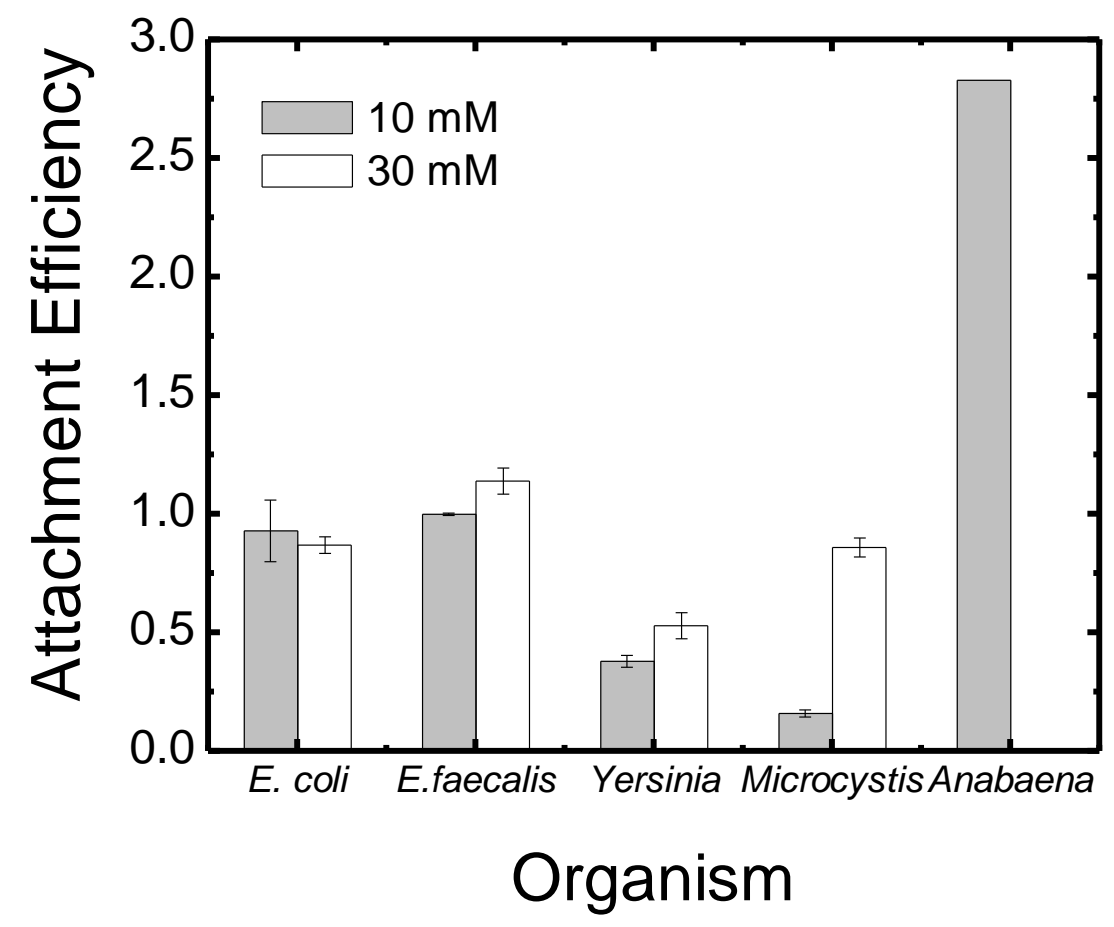

FIGURE 4. Mean attachment efficiencies calculated using eq 1 for transport of 5 different bacteria in columns packed with quartz sand at $10 \mathrm{mM}$ and $30 \mathrm{mM}$ IS (pH 5.9). 
To better understand whether DLVO interactions (i.e., electrostatic and van der Waals forces) play a dominant role in the observed bacterial attachment behavior, it is of interest to compare the calculated $\alpha$ values with the dimensionless parameter $N_{\text {DLVo defined by Elimelech }}$ (Elimelech, 1992). Elimelech (1992) used a combination of dimensional analysis and linear regression analysis to develop a semi-empirical approach for predicting particle attachment efficiency in granular porous media. Using a wide data set obtained from deposition studies with latex microspheres, he showed that the particle attachment efficiency, $\alpha$, can be characterized by a single dimensionless parameter, $N_{\text {DLVO: }}$

$$
N_{\text {DLVO }}=\frac{\kappa \mathrm{A}}{\varepsilon_{\mathrm{o}} \varepsilon_{\mathrm{r}} \psi_{\mathrm{c}} \psi_{\mathrm{b}}}
$$

where $\kappa$ is the inverse Debye length, $A$ is the Hamaker constant for the quartz-water-bacteria interaction (estimated as $6.5 \times 10^{-21} \mathrm{~J}$ ), $\psi_{\mathrm{c}}$ is the surface potential of the quartz grain, $\psi_{\mathrm{b}}$ is the surface potential of the bacterium, $\varepsilon_{\mathrm{o}}$ is the dielectric permittivity in a vacuum, and $\varepsilon_{\mathrm{r}}$ is the relative dielectric permittivity of water. The parameter $N_{\text {DLVo }}$ characterizes the DLVO interaction energy upon approach of a particle or a bacterium to the sand surface. By replacing the surface potentials with the zeta potentials of the bacteria (from Figure 1) and the zeta potentials of the quartz sand

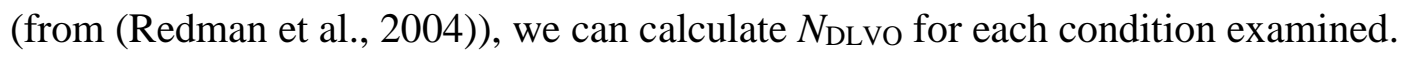

Redman et al (2004) and Walker et al (2004) found a direct relationship between bacterial attachment efficiencies and the parameter $N_{\text {DLVO }}$ for two of the three $E$. coli strains they examined (D21 and D21f2, but not JM109). The researchers attributed this strong relationship between $\alpha$ and $N_{\text {DLVO }}$ to the dominant role of DLVO forces in the bacteria-sand grain interaction. In Figure 5 , the bacteria attachment efficiencies determined in this study are plotted against the calculated parameter, $N_{\text {DLVO. }}$ For comparison, we also include previously reported data (open symbols) for 
transport of E. coli D21 (Walker et al., 2004), E. coli JM109 (Walker et al., 2004), and E. coli O157:H7 (Castro and Tufenkji, 2007) through columns packed with clean quartz sand. Inspection of Figure 5 reveals similarity in the results previously reported for E. coli O157:H7 and E. coli D21; namely, the slopes of the curves are nearly parallel (except at the highest $N_{\text {DLvo values where }}$ the bacterial deposition rate for E. coli $\mathrm{O} 157: \mathrm{H} 7$ has reached the maximum rate and exhibits a plateau). Also shown in Figure 5 is a data set (open triangles) calculated using the correlation equation developed by Elimelech (1992) based on the transport behavior of latex microspheres in columns packed with glass beads (i.e., $\left.\log \alpha=1.19 \log \left(N_{\text {DLVO }}\right)-1.59\right)$. The $\alpha$ values based on this correlation equation fall in between the data sets for E. coli $\mathrm{O} 157: \mathrm{H} 7$ and E. coli D21. 
$\triangle$ latex colloids/glass bead collector (Elimelech)

$\checkmark$ E. coli D21/quartz sand collector (Walker et al)

$\square$ E. coli JM109/quartz sand collector (Walker et al)

- E. coli O157:H7/quartz sand collector (Castro and Tufenkji)

- E. coli $\mathrm{O} 157: \mathrm{H} 7 /$ quartz sand collector (this study)

- E. faecalis/quartz sand collector (this study)

- Yersinia/quartz sand collector (this study)

- M. aeruginosa/quartz sand collector (this study)

- A. flos-aquae/quartz sand collector (this study)

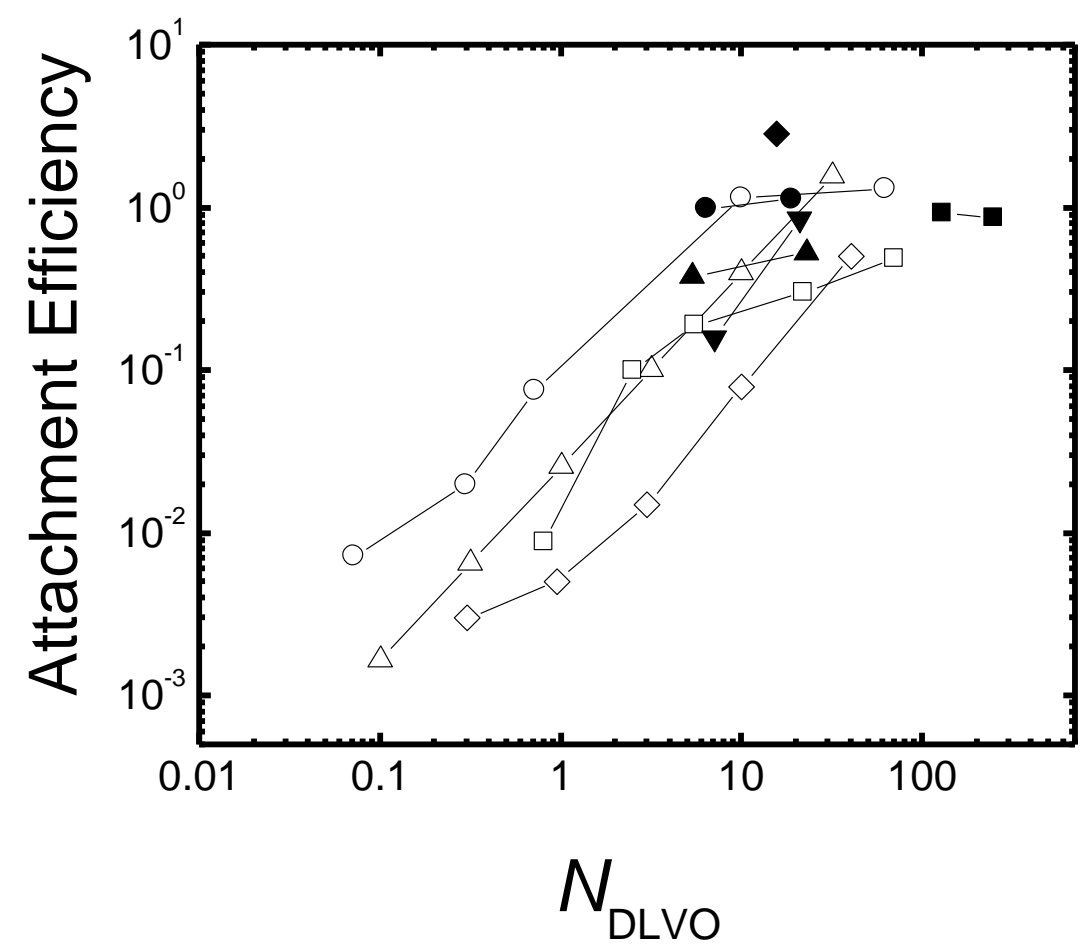

FIGURE 5. Relationship between calculated $\alpha$ values and the dimensionless parameter NDLVO. Data obtained from experiments with $(\triangle)$ latex colloids; $(\diamond)$ E. coli D21; $(\square)$ E. coli JM109; (O) E. coli

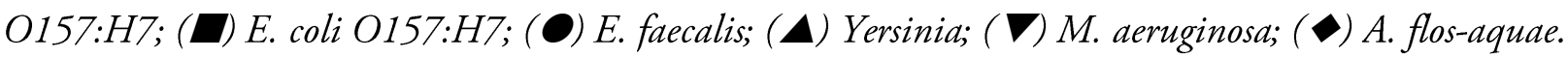

The solid symbols in Figure 5 show the results of experiments reported in the current study. Although the number of data points are limited (i.e., only two values of $N_{\text {DLVo }}$ for each organism), the two bacteria, $Y$. enterocolitica and $M$. aeruginosa, show a general increase in attachment efficiency with increasing $N_{\text {DLVOV}}$. Hence, the results obtained with these two organisms suggest that DLVO interactions play a dominant role in the transport and retention of these bacteria. 
Moreover, the results from the current study all fall directly on or very near the previously published data (where the appropriate data for calculating $N_{\text {DLVo }}$ are available). It is interesting that the data in Figure 5 generally show similar slopes for the individual data sets although they were obtained from experiments conducted in different laboratories using different collector media (e.g., sand, glass beads) and different particles/bacteria. For $\alpha$ values below 1, the data for E. coli O157:H7 from (Castro and Tufenkji, 2007) and the data for E. coli D21 from (Walker et al., 2004) yield a log-linearized slope of 1.1, which is nearly identical to that found by (Elimelech, 1992) for latex microspheres (1.2).

One of the organisms examined in this study - Anabaena flos-aquae - exhibits an $\alpha$ significantly greater than the theoretical "maximum" of 1 . It is not straightforward to evaluate the $\alpha$ value for this organism as it is filamentous in shape and significantly long (with strands as long as $160 \mu \mathrm{m}$ in length). It is also not surprising that the $\alpha$ value exceeds unity as this large organism likely experiences a great deal of physical straining during transport through the packed bed (Bradford et al., 2002). The ratio of the median filament length of A. flos-aquae to the median grain diameter is 0.052 indicating that removal by straining should be quite important for this cyanobacterium (Bradford et al., 2002). In contrast, the four other organisms examined here are much smaller in size (with $\mathrm{ESD} / d_{50}$ ratios between $1 \times 10^{-3}$ and $3 \times 10^{-3}$ ) and likely do not experience as much physical straining. Indeed, as discussed previously, Y. enterocolitica and M. aeruginosa both exhibit transport behavior that suggests DLVO interactions govern the extent of retention (note: E. coli $\mathrm{O} 157: \mathrm{H} 7$ has also been found to exhibit transport behavior that is in qualitative agreement with DLVO theory (Castro and Tufenkji, 2007), but this is not obvious in Figure 5 due to the chosen experimental conditions). Figure 5 suggests that the relationship between $\alpha$ and the $N_{\text {DLVo }}$ parameter may be of importance in better understanding the mechanisms governing the 
migration behavior of microbial pathogens and developing improved approaches for predicting their fate in the natural subsurface environment.

\subsection{Comparison of Bacteria Transport in Agricultural Soil.}

To better understand the usefulness of studies conducted under model conditions (e.g., clean quartz sand), an additional series of transport experiments was carried out using columns packed with natural agricultural soil obtained from a farm in Ste-Anne-de-Bellevue, Quebec. Although the soil columns were not extracted as undisturbed cores, a comparison of bacterial migration in sand versus soil is useful for evaluating the influence of collector grain properties on the filtration process. The collector media differ in terms of surface chemistry, geochemical heterogeneity, grain size distribution, and median grain size.

The grain size distributions of the quartz sand and the agricultural soil obtained by sieve analysis are shown in Figure 6a as a cumulative weight fraction chart. This analysis indicates that the size distribution of the quartz sand is quite uniform (i.e., coefficient of uniformity, $d_{60} / d_{10}=$ 1.2), whereas the size distribution of the agricultural soil is highly non-uniform $\left(d_{60} / d_{10}=2.4\right)$. The mean grain size $\left(d_{50}\right)$ of the quartz sand is $0.763 \mathrm{~mm}$ whereas the agricultural soil has a $d_{50}$ of $0.240 \mathrm{~mm}$. A plot of the particle size distributions (Figure 6b) reveals that the agricultural soil exhibits a distinct bimodal distribution in grain size. Such heterogeneity in grain size may impact the straining potential of the granular porous medium (Bradford et al., 2002). 

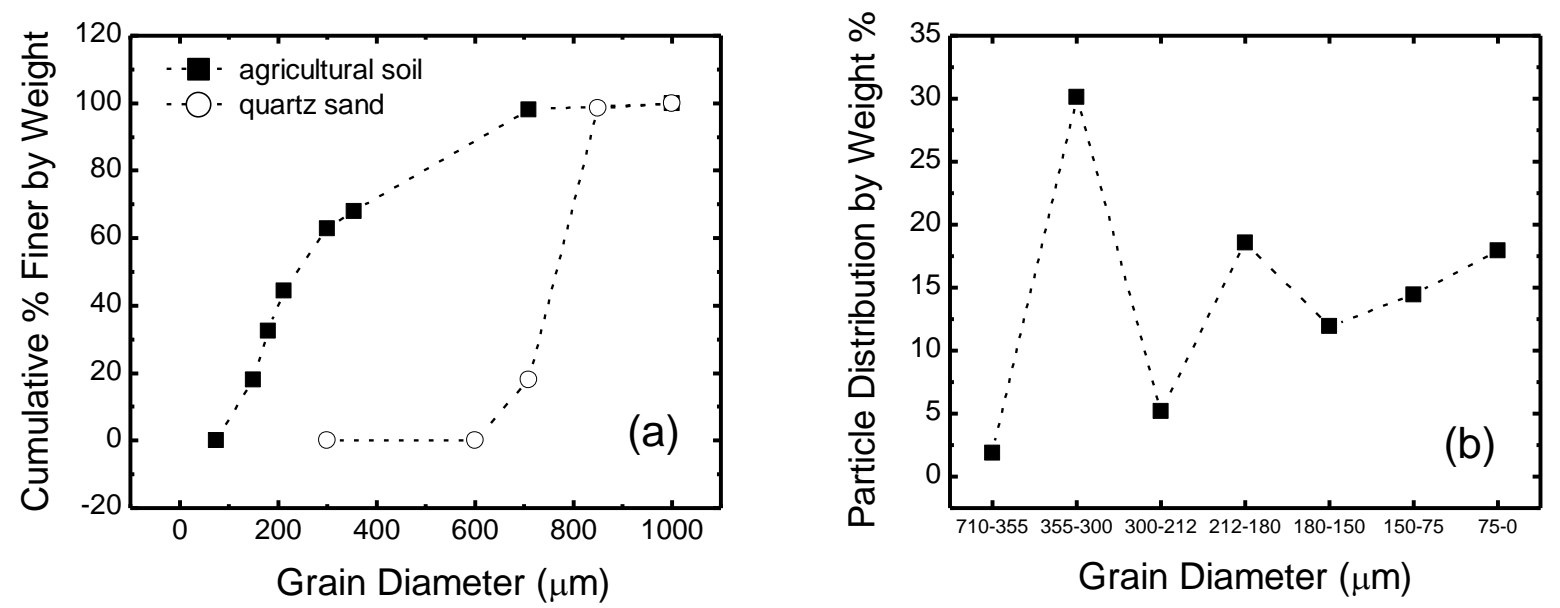

FIGURE 6. (a) Cumulative weight fraction chart for clean quartz sand and agricultural soil. (b) Particle size distribution for agricultural soil.

Transport experiments in soil columns were conducted using E. faecalis as a representative Gram-positive bacterium and E. coli $\mathrm{O} 157: \mathrm{H} 7$ as a representative Gram-negative organism. During the soil column experiments, samples of the column effluent were collected and used to monitor changes in solution $\mathrm{pH}$ and conductivity. The effluent $\mathrm{pH}$ was slightly higher $(\sim 6.6)$ than the influent $\mathrm{pH}$ (5.9) but stable over the duration of the experiment. The effluent conductivity was also stable over the length of each experiment and equal to the conductivity of the influent solution (data not shown). Representative breakthrough curves for E. faecalis and E. coli O157:H7 measured in $10 \mathrm{mM} \mathrm{KCl}$ are presented in Figures 7a and 7c, respectively. At $10 \mathrm{mM} \mathrm{IS,} \mathrm{14 \%} \mathrm{of}$ the E. coli $\mathrm{O} 157: \mathrm{H} 7$ cells are retained in the soil column in comparison to $53 \%$ of the E. faecalis cells. Transport experiments conducted at a higher IS of $30 \mathrm{mM}$ (Figure $7 \mathrm{~b}$ and $7 \mathrm{c}$ ) reveal that the extent of retention of $E$. coli is slightly greater (17\%), whereas E. faecalis exhibits significantly increased retention $(73 \%)$. Hence, the transport behavior of each organism in soil columns is generally in qualitative agreement with the DLVO theory of colloidal stability; namely, each organism experiences greater deposition with increased solution IS (i.e., with reduced repulsive 
electrostatic interactions). However, the more highly negatively charged organism (E. faecalis) $(\zeta$-potential data in Figure 1) does not exhibit a lower extent of retention, as may be expected based on DLVO theory. On the contrary, E. faecalis is retained to a much greater degree than E. coli in the natural soil columns. Hence, the bacterial transport behavior in the agricultural soil is not governed solely by DLVO interactions. Rather, non-DLVO type interactions and/or physical straining may influence the migration of these organisms in the soil system. 

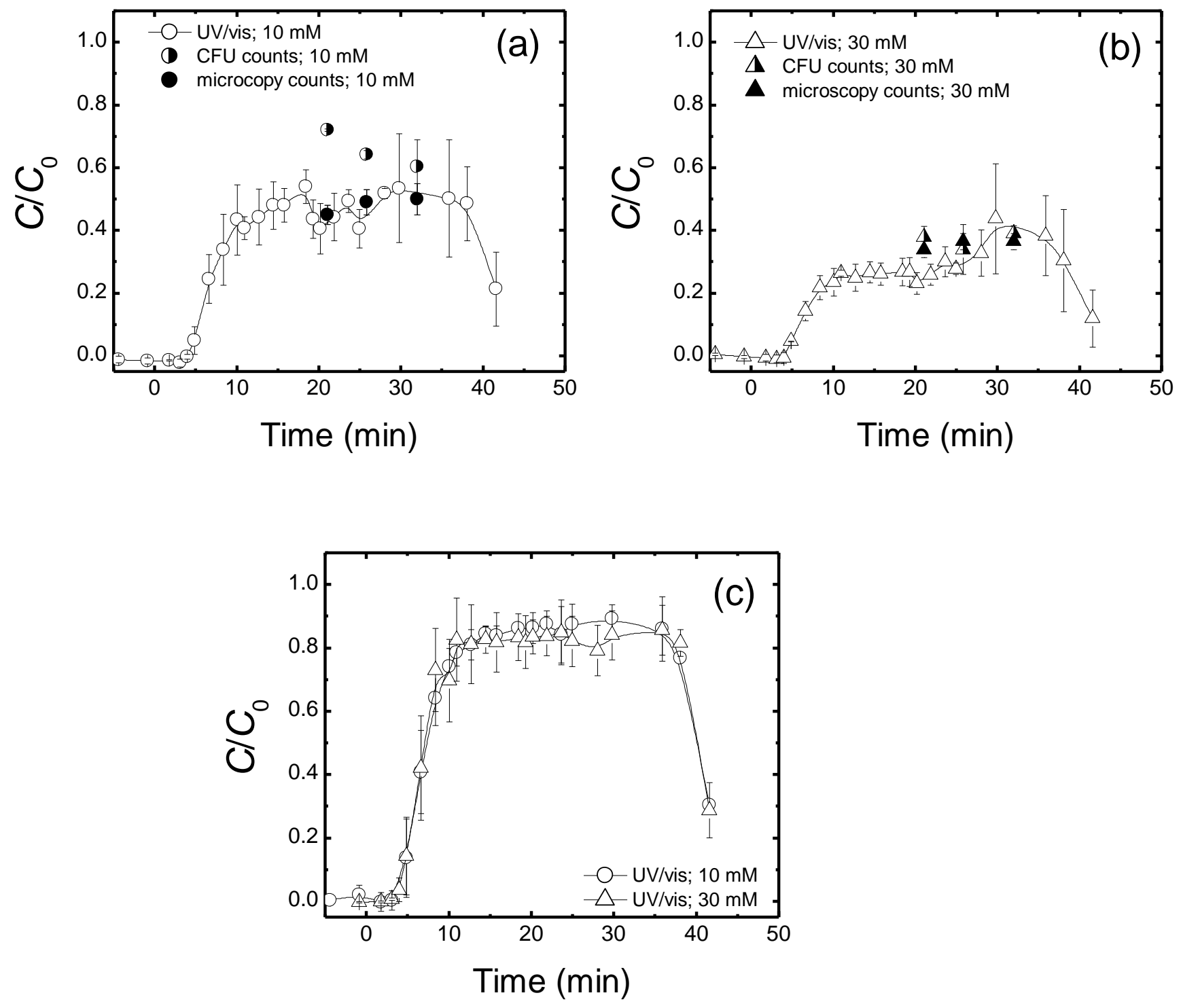

FIGURE 7. Representative breakthrough curves for transport of (a) E. faecalis at $10 \mathrm{mM}$ ionic strength, (b) E. faecalis at $30 \mathrm{mM}$ ionic strength, and (c) E. coli O157:H7 in columns packed with agricultural soil. For each breakthrough curve presented, average measurements from two separate experiments are shown. The column diameter was $1.6 \mathrm{~cm}$ and the fluid superficial velocity was $6.6 \times 10-5 \mathrm{~m} / \mathrm{sec}$.

In selected column experiments with natural soil, two additional bacteria enumeration methods were used for comparison with the breakthrough curves measured by spectrophotometry. Results of standard plate (CFU) counts and direct epifluorescence microscopy counts are plotted 
in Figure 7 (E. faecalis experiments). These additional observations are included here to confirm the validity of the absorbance measurements in Figure 7. In general, the microscopy method yields results that are close to those obtained with the UV/vis spectrophotometer. The average steadystate value of $C / C_{0}$ determined by microscopy is approximately $4 \%$ and $8 \%$ greater than that determined by spectrophotometry for the experiments conducted at $10 \mathrm{mM}$ and $30 \mathrm{mM}$, respectively. However, the CFU counts generally result in higher estimates of $C / C_{0}$. Specifically, the average steady-state value of $C / C_{0}$ determined by standard plate counts is approximately $29 \%$ and $13 \%$ greater than that determined by spectrophotometry for the experiments conducted at 10 $\mathrm{mM}$ and $30 \mathrm{mM}$, respectively. This observation can be explained by the fact that CFU counts yield the retention behavior of the culturable cells only, yet the bacteria eluting from the column are a combination of culturable, nonculturable, as well as nonviable cells. To our knowledge, a comparison of these different techniques (spectrophotometry, CFU counts, and direct microscopy counts) to measure bacteria breakthrough curves has not been previously demonstrated. Viability of the injected and eluted cells was verified using the BacLight Viability Kit (Molecular Probes) and was found to range between 81 and $96 \%$.

Because the agricultural soil exhibits a bimodal distribution in grain size, it is not straightforward to calculate $\alpha$ values from the data in Figure 7. Determination of $\alpha$ requires calculation of the single-collector contact efficiency $\left(\eta_{0}\right)$, which in turn depends on the mean collector diameter $\left(d_{c}\right)$. The median grain diameter of the agricultural soil $\left(d_{50}=240 \mu \mathrm{m}\right)$ is not necessarily representative of the porous medium as the soil is highly nonuniform in grain size. However, for the sake of quantitatively comparing the results obtained from the soil column study with the data from the quartz sand experiments, apparent attachment efficiencies were evaluated from each bacteria breakthrough curve. E. coli O157:H7 exhibits a lower apparent attachment 
efficiency in the agricultural soil $\left(\alpha_{\text {avg }}=0.082\right)$ than in the quartz sand $\left(\alpha_{\text {avg }}=0.90\right)$. Likewise, $\alpha$ values calculated for the E. faecalis transport experiments in soil columns are lower than those determined in clean quartz sand. For experiments conducted with E. faecalis in soil columns, the apparent $\alpha$ value is 0.39 at $10 \mathrm{mM}$ IS and 0.68 at $30 \mathrm{mM}$ IS. In contrast, the calculated $\alpha$ values for the quartz sand experiments are 1.0 at $10 \mathrm{mM}$ IS and 1.1 at $30 \mathrm{mM}$ IS. Although the $\alpha$ values determined for the soil experiments should be considered with caution, this comparison suggests that transport predictions based on attachment efficiencies measured in the sand experiments might underestimate bacterial migration potential in the agricultural soil.

\section{Conclusions}

The filtration behavior of five selected bacterial pathogens was examined in laboratory-scale columns packed with clean quartz sand at two IS and a $\mathrm{pH}$ near 6. Comparison of the results from this study with those previously reported indicates an interesting link between the experimental $\alpha$ value and the dimensionless parameter, $N_{\text {DLVO }}$. The noted importance of electrostatic interactions in colloid stability (i.e., colloid attachment to surfaces and colloid aggregation) emphasizes the value of microbe characterization studies reporting cell zeta potentials over a broad range of environmental conditions. In this study, the zeta potential of the five selected waterborne pathogens is presented over a broad range of $\mathrm{pH}$ values at two different solution IS. These data are of particular interest as some of the organisms considered have not been carefully examined previously.

In this study, selected experiments were also conducted with the representative Gramnegative pathogen E. coli $\mathrm{O} 157: \mathrm{H} 7$ and the Gram-positive pathogen E. faecalis in columns packed with loamy sand taken from an agricultural field. Calculated apparent attachment efficiencies for E. coli $\mathrm{O} 157: \mathrm{H} 7$ and E. faecalis in agricultural soil were found to be lower than those measured in 
the model quartz sand. It is interesting to compare the deposition behavior of these organisms in the two granular systems as E. faecalis and E. coli O157:H7 exhibit significantly different cell zeta potentials. Consideration of the transport and characterization data of these two organisms together suggests than non-DLVO mechanisms can also be involved in their retention behavior. The results of this investigation examining the surface properties and transport behavior of five waterborne pathogens highlights the need for additional studies in both soil and sand matrices over a broader range of environmentally relevant conditions to better understand possible links between the two systems. 


\section{Acknowledgements}

This research was supported by the Fonds québécois de la recherche sur la nature et les technologies (FQRNT Team Grant), the Canadian Water Network (CWN) and the Canada Foundation for Innovation (CFI). The authors acknowledge G. Faubert (McGill) and C. Madramootoo (McGill) for helpful discussions and access to the field site, S. Gruenheid (McGill) for providing ATCC 700927 and M. Assanta (AAFC) for providing ATCC 23715. 


\section{References}

Abu-Lail, N.I. and Camesano, T.A., 2003. The Role of Lipopolysaccharides in the Adhesion, Retention, and Transport of Escherichia coli JM109. Environ. Sci. Technol. 37, 2173-2183.

Banks, M.K., Yu, W. and Govindaraju, R.S., 2003. Bacterial Adsorption and Transport in Saturated Soil Columns. J. Environ. Sci. \& Health A38(12), 2749-2758.

Bolster, C.H., Mills, A.L., Hornberger, G. and Herman, J., 2001. Effect of surface coatings, grain size, and ionic strength on the maximum attainable coverage of bacteria on sand surfaces. J. Contaminant Hydrol. 50, 287-305.

Bolster, C.H., Walker, S.L. and Cook, K.L., 2006. Comparison of Escherichia coli and Campylobacter jejuni Transport in Saturated Porous Media. J. Environ. Qual. 35, 1018-1025.

Bradford, S.A., Yates, S.R., Bettahar, M. and Simunek, J., 2002. Physical factors affecting the transport and fate of colloids in saturated porous media. Water Resour. Res. 38(12), 1327-1338.

Brant, J., Lecoanet, H., Hotze, M. and Wiesner, M.R., 2005. Comparison of Electrokinetic Properties of Colloidal Fullerenes (n-C60) Formed Using Two Procedures. Environ. Sci. Technol. 39, 6343-6351.

Brown, D.G. and Jaffe, P.R., 2001. Effects of nonionic surfactants on bacterial transport through porous media. Environ. Sci. Technol. 35, 3877-3883.

Brown, D.G., Stencel, J.R. and Jaffe, P.R., 2002. Effects of porous media preparation on bacteria transport through laboratory columns. Water Res. 36(1), 105-114.

Brush, C.F., Ghiorse, W.C., Anguish, L.J., Parlange, J.Y. and Grimes, H.G., 1999. Transport of Cryptosporidium parvum oocysts through saturated columns. J. Environ. Qual. 28(3), 809-815.

Camesano, T.A. and Logan, B.E., 1998. Influence of Fluid Velocity and Cell Concentration on the Transport of Motile and Nonmotile Bacteria in Porous Media. Environ. Sci. Technol. 32, 1699-1708.

Castro, F.D. and Tufenkji, N., 2007. Relevance of NonToxigenic Strains as Surrogates for E. coli O157:H7 in Groundwater Contamination Potential: Role of Temperature and Cell Acclimation Time. Environ. Sci. Technol. 41, 4332-4338.

Dai, X. and Hozalski, R.M., 2002. Effect of NOM and biofilm on the removal of Cryptosporidium parvum oocysts in rapid filters. Water Res. 36, 3523-3532.

Dai, X. and Hozalski, R.M., 2003. Evaluation of Microspheres as Surrogates for Cryptosporidium parvum Oocysts in Filtration Experiments. Environ. Sci. Technol. 37, 1037-1042.

De Kerchove, A.J. and Elimelech, M., 2005. Relevance of Electrokinetic Theory for "Soft" Particles to Bacterial Cells: Implications for Bacterial Adhesion. Langmuir 21, 6462-6472.

Derjaguin, B.V. and Landau, L.D., 1941. Theory of the stability of strongly charged lyophobic sols and of the adhesion of strongly charged particles in solutions of electrolytes. Acta Physicochim. URSS 14, 733-762.

Dong, H., Onstott, T.C., Ko, C.H., Hollingsworth, A.D., Brown, D.G. and Mailloux, B.J., 2002. Theoretical prediction of collision efficiency between adhesion-deficient bacteria and sediment grain surface. Colloids and Surfaces B: Biointerfaces 24, 229-245.

Eboigbodin, K.E., Newton, J.R.A., Routh, A.F. and Biggs, C.A., 2005. Role of non-adsorbing polymers in bacterial aggregation. Langmuir 21, 12315-12319.

Elimelech, M., 1992. Predicting Collision Efficiencies of Colloidal Particles in Porous-Media. Water Res. 26(1), 1-8.

Foppen, J.W.A. and Schijven, J.F., 2005. Transport of E. coli in columns of geochemically heterogeneous sediment. Water Res. 39, 3082-3088.

Gallardo-Moreno, A.M., Gonzalez-Martin, M.L., Bruque, J.M., Perez-Giraldo, C. and Sanchez-Silos, R., 2003. Influence of the growth medium, suspending liquid and measurement temperature on the physico-chemical surface properties of two enterococci strains. J. Adhesion Sci. Technol. 17(14), 1877-1887.

Guimaraes, V.F., Cruz, I.V., Hagler, A.N., Mendonca-Hagler, L.C. and Van Elsas, J.D., 1997. Transport of a genetically modified Pseudomonas fluorescens and its parent strain through undisturbed tropical soil cores. Appl. Soil Ecology 7, 41-50.

Hahn, M.W., Abadzic, D. and O'Melia, C.R., 2004. Aquasols: On the Role of Secondary Minima. Environ. Sci. Technol. $38,5915-5924$. 
Harter, T., Wagner, S. and Atwill, E.R., 2000. Colloid transport and filtration of Cryptosporidium parvum in sandy soils and aquifer sediments. Environ. Sci. Technol. 34(1), 62-70.

Harvey, R.W. and Harms, H. (2001) Manual of Environmental Microbiology. Hurst, C.J. (ed), pp. 753-776, ASM Press, Washington, D.C.

Hekman, W.E., Heijnen, C.E., Burgers, S.L.G.E., van Veen, J.A. and van Elsas, J.D., 1995. Transport of bacterial inoculants through intact cores of two different soils as affected by water percolation and the presence of wheat plants. FEMS Microbiol. Ecology 16, 143-158.

Hijnen, W.A.M., Brouwer-Hanzens, A.J., Charles, K.J. and Medema, G.J., 2005. Transport of MS2 Phage, Escherichia coli, Clostridium perfringens, Cryptosporidium parvum, and Giardia intestinalis in a Gravel and a Sandy Soil. Environ. Sci. Technol. 39, 7860-7868.

Hsu, B.M. and Huang, C.P., 2002. Influence of ionic strength and $\mathrm{pH}$ on hydrophobicity and zeta potential of Giardia and Cryptosporidium. Colloids and Surfaces A: Physicochem. Eng.Aspects 201(1-3), 201-206.

Hunter, R.J., 2001. Foundations of Colloid Science, Oxford University Press, New York.

Huysman, F. and Verstraete, W., 1993. Water-facilitated transport of bacteria in unsaturated soil columns: Influence of inoculation and irrigation methods. Soil Biol. Biochem. 25(1), 91-97.

Jameson, G.J., 1999. Hydrophobicity and floc density in induced-air flotation for water treatment. Colloids and Surfaces A: Physicochem. Eng. Aspects 151, 269-281.

Kim, S.-B., Park, S.-J., Lee, C.-G., Choi, N.-C. and Kim, D.-J., 2008. Bacteria transport through goethite-coated sand: Effects of solution $\mathrm{pH}$ and coated sand content. Colloids and Surfaces B: Biointerfaces 63, 236-242.

Kuznar, Z.A. and Elimelech, M., 2004. Adhesion kinetics of viable Cryptosporidium parvum oocysts to quartz surfaces. Environ. Sci. Technol. 38(24), 6839-6845.

Li, Q. and Logan, B.E., 1999. Enhancing bacterial transport for bioaugmentation of aquifers using low ionic strength solutions and surfactants. Water Res. 33(4), 1090-1100.

Lytle, D.A., Johnson, C.H. and Rice, E.W., 2002. A systematic comparison of the electrokinetic properties of environmentally important microorganisms in water. Colloids and Surfaces B: Biointerfaces 24(2), 91-101.

Lytle, D.A., Rice, E.W., Johnson, C.H. and Fox, K.R., 1999. Electrophoretic mobilities of Escherichia coli O157:H7 and Wild-Type Escherichia coli strains Appl. Environ. Microbiol. 65(7), 3222-3225.

Marshall, K.C., 1984. Microbial adhesion and aggregation, Springer, Berlin Heidelberg.

Redman, J.A., Grant, S.B., Olson, T.M., Hardy, M.E. and Estes, M.K., 1997. Filtration of recombinant Norwalk virus particles and bacteriophage MS2 in quartz sand: Importance of electrostatic interactions. Environ. Sci. Technol. 31(12), 3378-3383.

Redman, J.A., Walker, S.L. and Elimelech, M., 2004. Bacterial adhesion and transport in porous media: role of the secondary energy minimum. Environ. Sci. Technol. 38, 1777-1785.

Rijnaarts, H.H.M., Norde, W., Bouwer, E.J., Lyklema, J. and Zehnder, A.J.B., 1996a. Bacterial deposition in porous media related to the clean bed collision efficiency and to substratum blocking by attached cells. Environ. Sci. Technol. 30(10), 2869-2876.

Rijnaarts, H.H.M., Norde, W., Bouwer, E.J., Lyklema, J. and Zehnder, A.J.B., 1996b. Bacterial deposition in porous media: Effects of cell-coating, substratum hydrophobicity, and electrolyte concentration. Environ. Sci. Technol. 30(10), 2877-2883.

Rivas, L., Fegan, N. and Dykes, G.A., 2005. Physicochemical properties of Shiga toxigenic Escherichia coli. J. Appl. Microbiol. 99, 716-727.

Ryan, J.N. and Elimelech, M., 1996. Colloid mobilization and transport in groundwater. Colloids and Surfaces A: Physicochem. Eng. Aspects 107, 1-56.

Salerno, M.B., Flamm, M., Logan, B.E. and Velegol, D., 2006. Transport of Rodlike Colloids through Packed Beds. Environ. Sci. Technol. 40, 6336-6340.

Smith, J.E. and Perdek, J.M., 2004. Assessment and management of watershed microbial contaminants. Crit. Rev. Environ. Sci. Technol. 34, 109-139.

Tong, M.P., Camesano, T.A. and Johnson, W.P., 2005. Spatial Variation in Deposition Rate Coefficients of an AdhesionDeficient Bacterial Strain in Quartz Sand. Environ. Sci. Technol. 39, 3679-3687. 
Tufenkji, N., 2006. Application of a Dual Deposition Mode Model to Evaluate Transport of Escherichia coli D21 in Porous Media. Water Resour. Res. 42(12), W12S11.

Tufenkji, N., 2007. Modeling Microbial Transport in Porous Media: Traditional Approaches and Recent Developments. Adv. Water Resour. 30, 1455-1469.

Tufenkji, N. and Elimelech, M., 2004. Correlation Equation for Predicting Single-Collector Efficiency in Physicochemical Filtration in Saturated Porous Media. Environ. Sci. Technol. 38, 529-536.

Tufenkji, N., Ryan, J.N. and Elimelech, M., 2002. The promise of bank filtration. Environ. Sci. Technol. 36(21), 422a428a.

van der Wal, A., Minor, M., Norde, W., Zehnder, A.J.B. and Lyklema, J., 1997. Electrokinetic potential of bacterial cells. Langmuir 13(2), 165-171.

van Merode, A.E.J., Van der Mei, H.C., Busscher, H.J. and Krom, B.P., 2006. Influence of Culture Heterogeneity in Cell Surface Charge on Adhesion and Biofilm Formation by Enterococcus faecalis. J. Bacteriology 188(7), 2421-2426.

Verwey, E.J.W. and Overbeek, J.T.G., 1948. Theory of the Stability of Lyophobic Colloids, Elsevier, Amsterdam.

Walker, S.L., Redman, J.A. and Elimelech, M., 2004. Role of Cell Surface Lipopolysaccharides (LPS) in Escherichia coli K12 Adhesion and Transport. Langmuir 20, 7736-7746.

Weiss, T.H., Mills, A.L., Hornberger, G.M. and Herman, J.S., 1995. Effect of bacterial cell shape on transport of bacteria in porous media. Environ. Sci. Technol. 29, 1737-1740.

World Resources Institute, 2000. A Guide to World Resources 2000-2001: People and Ecosystems: The Fraying Web of Life, Washington, D.C.

Xu, S., Liao, Q. and Saiers, J.E., 2008. Straining of Nonspherical Colloids in Saturated Porous Media. Environ. Sci. Technol. 42, 771-778.

Yao, K.M., Habibian, M.T. and O'Melia, C.R., 1971. Water and Waste Water Filtration - Concepts and Applications. Environ. Sci. Technol. 5(11), 1105-1112. 